\title{
Upper GI Bleed
}

\author{
Chris Steele
}

Patients who are admitted to hospital with upper GI who are hypotensive $(<100 \mathrm{mmHg})$ for more than $30 \mathrm{~min}$ need to be admitted to a high dependency unit

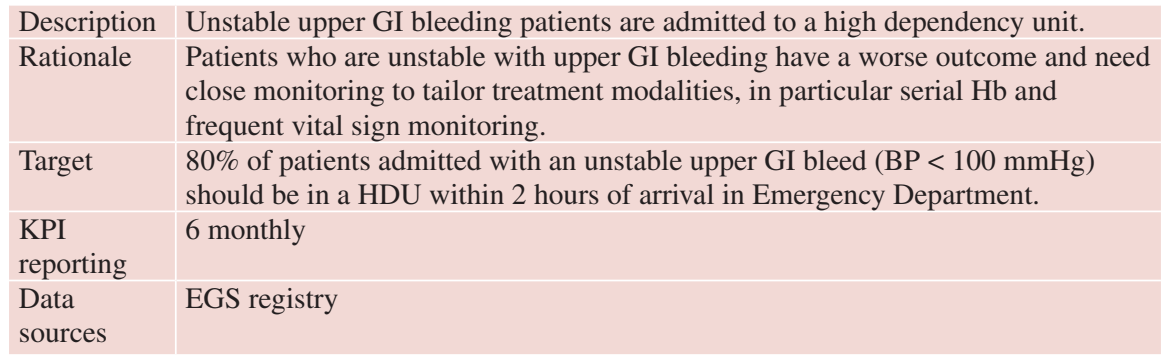

Patients with blood per rectum have their anticoagulants stopped on admission and are not charted for heparins in the first 12 hours post admission

\begin{tabular}{|c|c|}
\hline Description & $\begin{array}{l}\text { Patients with blood per rectum have their anticoagulants stopped on admission } \\
\text { and are not charted for heparins in the first } 12 \text { hours post admission. This would } \\
\text { include antiplatelet agents and warfarin. }\end{array}$ \\
\hline Rationale & $\begin{array}{l}\text { Patients who present with blood per rectum may be on anticoagulants, usually for } \\
\text { atrial fibrillation. They may have a recent stent or history of thromboembolic } \\
\text { phenomenon. Failure to stop these medications at least for the first few hours of } \\
\text { admission could result in more significant hemorrhage. }\end{array}$ \\
\hline Target & $95 \%$ of patients admitted for blood per rectum have their anticoagulants stopped. \\
\hline $\begin{array}{l}\text { KPI } \\
\text { reporting }\end{array}$ & 6 monthly \\
\hline $\begin{array}{l}\text { Data } \\
\text { sources }\end{array}$ & EGS registry \\
\hline
\end{tabular}

\author{
C. Steele $(\bowtie)$ \\ Letterkenny University Hospital, Letterkenny, Co. Donegal, Ireland \\ e-mail: Chris.Steele@hse.ie
}

